\title{
Ageing and Job Performance: Methodological Issues and Empirical Evidence
}

\author{
HASSAN ALI \\ School of Management \\ Universiti Utara Malaysia
}

\begin{abstract}
This article reviews the methodological difficulties involved in research on age and job performance. It also examines the empirical evidence of the relationship between age and job performance. Research in this area has been conducted in both laboratory as well as occupational settings. Research in occupational settings has generally utilized either output measures or performance evaluations to measure job performance. Evidence from the literature has generally found no conclusive relationship between age and job performance. Studies have also found experience rather than age predicts job performance to a greater extent than age.
\end{abstract}

\begin{abstract}
ABSTRAK
Artikel ini melibat masalah metodologi dalam penyelidikan hubungan di antara umur dan prestasi. Artikel ini juga melihat bukti empiri hubungan ini. Penyelidikan dalam bidang ini telah dijalankan dalam maklmal dan organisasi kerja. Penyelidikan di tempat kerja menggunakan sama ada ukuran output atau penilaian prestasi untuk mengukur prestasi kerja. Bukti dari kajian-kajian lepas tidak muktamad menunjukkan ada hubungan di antara umur dan prestasi. Kajian-kajian ada juga menunjukkan pengalaman lebih boleh meramalkan prestasi kerja daripada umur.
\end{abstract}

\section{INTRODUCTION}

Industrial gerontology (Murrell, 1959) is an area of research that examines the occupational aspects of ageing. It is concerned mainly with the study of the employment and retirement problems of middle-aged and older workers (Sprague, 1970). An important area in the occupational aspect of ageing is job performance. Generally, older workers are unfavorably stereotyped whereby it is widely believed that job performance declines with age (Rhodes, 1983). The research literature on age and job performance is relatively small compared to other areas of research in ageing. The aim of this paper is to examine the methodological difficulties facing the investigation of age difference in job performance in occupational settings. It will also examine an empirical evidence of research on ageing and job performance conducted in laboratory studies and occupational settings.

\section{METHODOLOGICAL ISSUES}

The research literature on age and job performance in the occupational setting is relatively small. This is partly because the investigation of work behaviour in relation 
to age involves methodological difficulties (Davies, Taylor \& Dorn, 1992; Griew, 1959; Smith, 1981; Welford, 1958). Production records, which appear to provide valuable and informative data on job performance, may have serious limitations (Welford, 1958). For example employees who consistently show a declining output may be transferred to other work or in extreme cases dismissed. As a result, as Davies, Matthews and Wong (1991) observed, if productivity decreases with age, then those more productive older workers remaining on the job will be unrepresentative of their age cohort, and any comparison of the productivity of different age groups will tend to favour older workers. On the other hand, older workers who perform well may be promoted to supervisory positions, leaving less productive workers behind. Therefore any age comparison carried out will tend to favour younger workers. Davies and Sparrow (1985) suggest that age comparisons of job performance are only meaningful when the turnover and internal rates of transfer are low. Further, any age comparison requires large samples of workers within different age groups who are all engaged on exactly the same work. Welford (1958) argued that minor differences in job characteristics might conceal major differences in the demands made on an employee's skills and abilities.

\section{LABORATORY STUDIES}

Early laboratory studies demonstrated age-related declines in several psychological function involving sensory and motor mechanisms, memory and information processing (Welford, 1958). In tasks that are complex and demanding, the older people have been found to be disadvantaged (McDowd \& Craik, 1988; Welford, 1977). There are two possible explanations for the sensitivity of complex task- to age-related changes. Birren, Woods and Williams (1980) suggested that older people have a lower 'mental speed' and execute elementary information processes more slowly than younger people. Therefore younger people have a speed advantage over older people in complex task performance because of the greater number of elementary processes required to complete a task. Second, the specific components of complex task performance may be selectively impaired with increasing age. Cerella (1985) noted that central computational processing was slower among older people than younger people, while Charness (1985) noted greater memory deficits among older than among younger individuals. Dobson, Kirasic and Allen (1995) observed greater age-related performance decrements as the complexity of spatial task performance (figure comparison task) was increased.

Teeken, Adam, Paas, van Boxtel, Houx and Jolles (1996) investigated the effects of age on discrete and reciprocal aiming movements among patients attending general practices in the region of Maastricht, in The Netherlands. The task required participants to make one discrete aiming movement, while the reciprocal task required participants to make a series of back-and-forth movements. The study found that there were significant age effects for both discrete and reciprocal aiming movements. Increasing age was strongly associated with slower movements. The study also obtained a significant age by task interaction, there being a greater ageing effect for the discrete task than for the reciprocal task.

Salthouse, Hambrick, Lukas and Dell (1996) used a synthetic work approach to evaluate adult age differences in job performance. The synthetic work approach simulated complex work activities by requiring participants to perform several concurrent tasks in a laboratory setting. The study used Elsmore's (1994) SYNWORK1 computer programme that was designed to incorporate the dynamic aspects of complex work activities. It consists of four tasks: memory, arithmetic, visual monitoring and auditory monitoring. In addition to these tasks, the synthetic work situation also required time management skills, to deal with multiple concurrent demands. This study involved two separate experiments in which adults of different ages performed the four tasks during 25 sessions in a synthetic work situation for five-minute periods over 
three days. In both the experiments it was found that there were large age differences in time management skills. As age increased, individuals were less able to deal successfully with several concurrent tasks and were often observed to neglect more difficult tasks in order to deal with easier ones.

\section{ORGANISATIONAL STUDIES}

Studies examining age differences in job performance in the occupational setting have used two types of job performance measures, namely output measures and performance evaluation using ratings and ranking. This section examines the empirical evidence of the relationship between age and job performance in the occupational setting. First an empirical review of studies using the meta-analysis technique is carried out. Then a review of studies using output measure and performance evaluation to examine the relationship between age and job performance is discussed.

\section{EMPIRICAL REVIEW}

Most reviews on age and job performance have generally concluded that there was no conclusive relationship between age and job performance (Davies \& Sparrow, 1985; Davies, Matthews \& Wong, 1991; McEvoy \& Cascio, 1989; Rhodes, 1983; Waldman \& Avolio, 1986; Warr, 1994). Rhodes (1983) conducted a comprehensive review of the age and job performance relationship. Her review reported mixed results on the relationship. Of the 34 studies that reported age and job performance relationships, eight reported a positive relationship, nine a negative relationship, eight an inverted- $U$ relationship, and nine obtained no significant relationship between age and job performance. Rhodes (1983) also considered the role of experience. Of the three studies reviewed, two reported an attenuating effect of experience on the relationship between age and job performance. Performance was essentially the same across age groups when experience was controlled. Avolio, Waldman and McDaniel (1990) examined the work performance of individuals in different occupations to determine whether experience contributes to the prediction of work performance beyond the contribution of age. The study found that, across occupations, experience was more highly correlated with job performance than was age. The age-performance correlation dropped substantially when experience was controlled. However the experience-performance relationship changed very little when age was controlled.

McEvoy and Cascio (1989) carried out a metaanalysis of research on the relationship between age and job performance conducted over 22 years and published in 46 behavioural science journals. The study found a total of 96 independent studies with a total sample size of 38,983 from a broad cross-section of jobs and age groups that reported age-performance correlations. The study concluded that age and job performance was essentially unrelated. There was also no evidence that the type of performance measure (rating vs. productivity measures) or the type of job (professional vs. non-professional) significantly moderated the age-job performance relationship.

Waldman and Avolio (1986) also conducted a meta-analysis to examine the relationship between age and job performance. The study reviewed 40 samples that were classified into three categories according to the type of performance measures used. The three categories were supervisory ratings, peer ratings and individual productivity. The study also classified the type of job into professional and non-professional groups. For productivity measures, job performance increased with age. However this positive relationship was small in magnitude and correlations were much the same for professional and non-professional groups. Waldman and Avolio (1986) also reported that for supervisory ratings, the correlations between age and job performance for both professional and nonprofessional groups were negative and significant. They suggested that the different results obtained for 
productivity measures and supervisory ratings may be due to rater bias when ratings were used, so that the productivity measures may be a fairer and more appropriate representation of actual performance.

\section{Output Measures}

Production records or output data are the most satisfactory methods of assessing the relationship between age and job performance (Davies, Matthews \& Wong, 1991). In an early study, Clay (1956) examined age differences in productivity among machine operators, hand compositors and proofreaders at two British printing works. The turnover rates among employees were negligible. The study found that performance peaked among employees in their forties and thereafter declined. Schwab and Heneman (1977) investigated the relationship between work productivity, age and experience among production workers performing tasks that involved manual dexterity. The workers in the study were semi-skilled assemblers and moderately skilled sewing machine operators and machine tenders who were paid under a standard time, piece-rate pay system. Output data were obtained from the firm's engineering department and an average hourly productivity value was computed. The study found the correlation between age and performance was near zero and nonsignificant. However when age was controlled, the correlation between experience and performance was positive and significant. These findings suggest that experience predicts performance to a greater extent than does age.

Giniger, Dispenzieri and Eisenberg (1983) also investigated the relationship between age, experience and worker productivity. The study was carried out in the garment manufacturing industry. The workers were classified in terms of the job tasks that required speed and the job tasks that required skill. Employee turnover was minimal during the period of study. Production data were obtained from company records and productivity was measured in terms of average hourly piece-rate wages. It was found that for both speed and skill job tasks, productivity of the older workers surpassed that of the younger ones. Partial correlations between experience and performance (controlling for age) indicated experience rather than age moderated performance, with the older workers being more experienced than the younger workers.

Ali (1999) investigated the relationships between age, experience and job performance of blue-collar workers doing essentially the same job and paid the same wages. The subject comprised 1053 rubber tappers from nine different estates in Malaysia. The turnover rate of rubber tappers was low and the internal transfer rate was non-existant. The subjects had little or no education at all. Two performance measures were derived from production record: total crop and out turn. Since terrain varied across the nine plantations the interaction of terrain with age and its effect on job performance was also examined. Terrain was classified as either hilly or undulating. The study also examined whether experience contributed to the prediction of job performance beyond the contribution of age. Results indicated a significant main effect of age on both performance measures. The relationship between age and job performance was an inverted U-relation. Job performance increased with age, peaked in the mid-forties and declined thereafter. The interaction of age with terrain on job performance was found to be not significant. Terrain did not differentially affect job performance of the younger and the older rubber tappers. The study also found that the rubber tappers' experience rather than age determined job performance of rubber tappers.

Sparrow and Davies (1988) investigated the effects of age, tenure, training level and job complexity (indexed by the size of machine serviced) on the job performance of service engineers servicing photocopiers for a multinational office equipment company in the United Kingdom. Turnover and internal transfer rates among employees were low. The educational levels were similar across age cohorts. Two output measures were obtained from company records. The first measure was the quality of service achieved, 


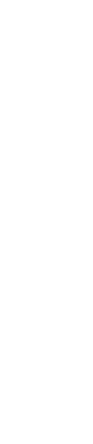

\section{Performance Evaluation}

Job performance may also be measured through performance ratings, which are usually made by supervisors. However ratings may be less satisfactory than objective measures (Landy \& Farr, 1983). Cattell and Kline (1977) suggest ratings tend to be unreliable across time and are susceptible to rater bias. Ratings may also be influenced by stereotypes held by the rater and this may affect older workers, who are often discriminated against in performance evaluation, due to negative stereotyping of older workers (Davies, Matthews \& Wong, 1991).

Despite negative stereotyping, research has shown no significant differences in job performance rating given to older and younger workers. Vecchio (1993) investigated the impact of differences in subordinate and supervisor age on job performance of high school teachers. Specifically, the study examined difference in age that exists between rater and ratee and how it influences the ratings of subordinate performance. The study found no evidence of a negative relationship between age and job performance. Interestingly, the study found supervisors were more likely to give subordinates who were older than they were more favourable evaluations, although the magnitude of this effect was not substantial.
However, some studies have obtained age differences in job performance ratings. Studies examining the job performance of American air-traffic controllers have reported age was negatively related to pre-training aptitude test scores, objective performance measures and performance ratings given by supervisors, crew chiefs and peers (Cobb, Nelson \& Matthews, 1973; Trites \& Cobb, 1962). Dalton and Thompson (1971) and Price, Thompson and Dalton (1975) examined the job performance of engineers employed in large technological companies. Performance ratings were obtained from the managers of the engineers. The study found rated performance increased initially, peaked in the mid-thirties and declined thereafter. Horner (1980) examined the performance rating of middle-level managers working in a large American public utility company. The study found that managers who were over the age of 50 tended to be rated as less receptive to new ideas and as slower to acquire new skills. However, these groups of managers were more technically competent than younger managers. In a more recent study, Shore and Bleicken (1991) examined the relationship between age and performance ratings among assemblers in a large electronics manufacturing company. The study used performance evaluation forms similar to those used by the company. Performance ratings were made on six dimensions: work quality, work quantity, judgment, initiative, teamwork and dependability. Ratings were obtained from the employees themselves as well as their supervisors. In general, a trend was observed for selfratings to be higher than supervisory ratings. This effect was fairly consistent regardless of the age of the subordinates and the age of the supervisor. The study also noted that the most consistent rating congruence was observed among the older workers. On the specific dimension of judgment, it was found that subordinates age did not affect self-ratings. On the other hand supervisory ratings on this dimension were consistently higher for older workers than for younger workers. Shore and Bleicken (1991) suggest that the reason for this was that judgment was a quality that was typically associated with increasing age and experience. 


\section{CONCLUSION}

Studies on age and job performance face considerable methodological difficulties. In undertaking research on age differences in job performance, it is important to ensure that employee turnover, particularly voluntary turnover, is minimal, and internal transfer rates are low. Further, a large sample of workers engaged in exactly the same work is crucial for a meaningful comparison to be carried out on job performance of older and younger workers. Most reviews on age and job performance have generally found no conclusive relationship between age and job performance. Studies examining age difference in job performance use either output measures or performance rating to measure job performance. Output measures are generally a more satisfactory method in assessing the relationship between age and job performance. Performance ratings are a less satisfactory method than output measures because they are unreliable across time, are susceptible to rater bias, and influenced by stereotypes held about older workers. Most studies of age and job performance have generally found that experience predicts job performance to a greater extent than does age.

\section{REFERENCES}

Ali, H. (1999). Individual differences in work behaviour of blue-collar workers : A study of rubber tappers in Malaysia. Unpublished doctoral dissertation, Aston University, England.

Avolio, B.J., Waldman, D.A., \& McDaniel, M.A. (1990). Age and work performance in nonmanagerial jobs: The effects of experience and occupational type. Academy of Management Journal, 33, 407-422.
Birren, J.E., Woods, A.M., \& Williams, M.V. (1980) Behavioral slowing with age-causes, organization and consequences. In L.W. Poon (Ed.), Ageing in the 1980s. Washington DC: American Psychological Association.

Cattell, R.B., \& Kline, P. (1977). The Scientific Analysis of Personality and Motivation. New York: Academic Press.

Cerella, J. (1985). Information processing rates in the elderly. Psychological Bulletin, 98, 67-83.

Charness, N. (1985). Ageing and problem-solving performance. In N. Charness (Ed.), Ageing and Human Performance. Chichester: John Wiley \& Sons.

Clay, H.M. (1956). A study of performance in relation to age at two printing works. Journal of Gerontology, 11, 417-424.

Cobb, B.B., Nelson, P.L., \& Matthews, J.J. (1973). The Relationships of Age and ATC Experience to Job Performance. FAA Civil Aeromedical Institute.

Dalton, G.W., \& Thompson, P.H. (1971). Accelerating obsolescence of older engineers. Harvard Business Review, 49, 57-68.

Davies, D.R., Matthews, G., \& Wong, C.S.K. (1991). Ageing and work. In C.L. Cooper \& I.T. Robertson (Eds.), International Reviews of Industrial and Organizational Psychology, (6). Chichester: John Wiley \& Sons.

Davies, D.R., \& Sparrow, P.R. (1985). Age and work behaviour. In N. Charness (Ed.), Ageing and Human Performance. Chichester: John Wiley \& Sons. 
Davies, D.R., Taylor, A., \& Dorn, L. (1992). Ageing and human performance. In A.P. Smith \& D.M. Jones (Eds.), Handbook of Human Performance: State and Trait, 3. London: Academic Press.

Dobson, S.H., Kirasic, K.C., \& Allen, G.L. (1995). Age-related differences in adults' spatial task performance: Influences of task complexity and perceptual speed. Ageing and Cognition, 2, 19-38.

Giniger, S., Dispenzieri, A., \& Eisenberg, J. (1983). Age, experience, and performance on speed and skills jobs in an applied setting. Journal of Applied Psychology, 68, 469-475.

Griew, S. (1959). Methodological problems in industrial ageing research. Occupational Psychology, 33, 36-45.

Horner, P. (1980). Construction and implementation of an alternative performance rating scale and possible age group and managerial level effects on performance ratings. Unpublished MA thesis, Wayne State University.

Landy, F.J., \& Farr, J.L. (1983). The Measurement of Work Performance: Methods, Theory, and Applications. San Diego, CA: Academic Press Inc.

McDowd, J.M., \& Craik, F.I.M. (1988). Effects of ageing and task difficulty on divided attention performance. Journal of Experimental Psychology: Human Perception and Performance, 14, 267-280.

McEvoy, G.M., \& Cascio, W.F. (1989). Cumulative evidence of the relationship between employee age and job performance. Journal of Applied Psychology, 74, 11-17.
Murrell, K.F.H. (1959). Major problems of industrial gerontology. Journal of Gerontology, 34, 275279.

Price, J.L., Thompson, P.H., \& Dalton, G.W. (1975). A longitudinal study of technological obsolescene. Research Management, Nov., 2228.

Rhodes, S.R. (1983). Age-related differences in work, attitudes and behavior: A review and conceptual analysis. Psychological Bulletin, 93, 328267.

Salthouse, T.A., Hambrick, D.Z., Lukas, K.E., \& Dell, T.C. (1996). Determinants of adult age differences on synthetic work performance. Journal of Experimental Psychology: Applied, 2, 305-329.

Schwab, D.P., \& Heneman, H.G. (1977). Effects of age and experience on productivity. Industrial Gerontology, 4, 113-117.

Shore, L.M., \& Bleicken, L.M. (1991). Effects of supervisor age and subordinate age on rating congruence. Human Relations, 44, 1093-1105.

Smith, J.M. (1981). Over forties in manual and technical work. In C.L. Cooper \& D.P. Torrington (Eds.), After Forty. Chichester: John Wiley \& Sons.

Sparrow, P.R., \& Davies, D.R. (1988). Effects of age, tenure, training, and job complexity on technical performance. Psychology and Ageing, 3, 307-314.

Sprague, H. (1970). Preface. In H.L. Sheppard (Ed.), Towards an Industrial Gerontology. Cambridge, Massachusetts: Schenkman. 
Teeken, J.C., Adam, J.J., Paas, F.G.W.C., Van B.M.P.J., Houx, P.J., \& Jolles, J. (1996). Effects of age and gender on discrete and reciprocal aiming movements. Psychology and Ageing, 11, 195198.

Trites, D.K., \& Cobb, B.B. (1962). Problems in Air Traffic Management: III. Implications of Age for Training and Job Performance of Air Traffic Controllers. FAA Civil Aeromedical Research Institute, Report No. 62-3.

Vecchio, R.P. (1993). The impact of differences in subordinate and supervisor age on attitudes and performance. Psychology and Ageing, 8, 112119.
Waldman, D.A., \& Avolio, B.J. (1986). A meta-analysis of age differences in job performance. Journal of Applied Psychology, 71, 33-38.

Warr, P. (1994). Age and employment. In M. Dunnette, L. Hough, \& H. Triandis (Eds.), Handbook of Industrial and Organisational Psychology, 4. Palo Alto, CA: Consulting Psychologist Press.

Welford, A.T. (1958). Ageing and Human Skills. London: Oxford University Press.

Welford, A.T. (1977). Motor performance. In J.E. Birren \& K.W. Schaie (Eds.), Handbook of The Psychology of Ageing. New York: Van Nostrand. 